\title{
Ajaran Syeikh Nawawi al-Bantani Tentang Pendidikan Akhlak Anak
}

\author{
M. Azizzullah Ilyas \\ Institut Agama Islam Negeri (IAIN) Curup \\ alcurufi@gmail.com
}

\begin{abstract}
Cultural and technological developments have an effect on children, positive and negative effects, these developments also effect in children's morality toward his parents. This erosion of moral values is interesting to study. We tried to see the moral values through the teachings of Sheikh Nawawi al-Bantani, a classical Indonesian scholar, his teachings goals and relevance for contemporary education. This research is a qualitative research by analyzing the main sources of Tafsir Marahil labid and Maraqi Ubudiyah Syarah Bidayah Hidayah. This study concludes that the teachings of Sheikh Nawawi Al-Bantani lead to the form of moral competence that does not stop at morality at the level of cognition and emotion, but rather integrates it with moral actions. His teachings combine adherence to God and devotion to parents as two things that cannot be separated but still make obedience to God as the main foundation.
\end{abstract}

Keywords :Nawawi al-Bantani, Children Education, Moral

Abstrak :Perkembangan budaya dan teknologi memberikan efek kepada anak baik efek positif ataupun negatif, perkembangan tersebut juga berpengaruh kepada akhlak anak kepada orang tua. Tergerusnya nilai-nilai akhlak saat ini menarik untuk dikaji. Kita mencoba melihat nilai-nilai akhlak lewat ajaran Syeikh Nawawi al-Bantani seorang ulama Indonesia klasik, tujuan serta relevansinya untuk pendidika kekinian. Penelitian ini adalah penelitian kualitatif dengan menganalisa sumber utamatafsir marahil labid dan Maraqi Ubudiyah Syarah Bidayah Hidayah. Penelitian ini menyimpulkan bahwa Ajaran-ajaran Syeikh Nawawi Al-Bantani mengarah kepada pembentukan kompetensi akhlak yang bukan berhenti pada akhlak pada tataran kognisi dan emosi saja, melainkan memadukannyadengan tindakan akhlak. Ajarannya memadukan antara ketaatan kepada Tuhan dan kebaktian kepada kedua orang tua sebagai dua hal yang tidak bisa dipisahkan namun dengan tetap menjadikan ketaatan kepada Tuhan sebagai pondasi utama.

AR-RIAYAH : Jurnal Pendidikan Dasar vol. 2, no. 2, 2018

STAIN Curup - Bengkulu| pISSN2580-362X;e ISSN2580-3611

http://journal.staincurup.ac.id/index.php/JPD 
114 AR-RIAYAH : Jurnal Pendidikan Dasar vol. 2, no. 2, 2018

Kata Kunci : Nawawi al-Bantani,Pendidikan Anak, Akblak.

\section{PENDAHULUAN}

Akhlak merupakan perkara penting yang menandakan manusia berpendidikan dan berbudaya. manusia menjadi berbeda dari binatang karena ada akal dan hati selain nafsu. Akalberperan sebagai sarana untuk berpikir dan mempertimbangkan yang benar dan yang salah, baik dan buruk, indah dan jelek. Akal yang membedakan apakah sesuatu itu baik atau buruk dan yang bertindak memberikan keputusan adalah hati apakah akan memilih yang baik atau memilih yang buruk. Bisa saja seseorang mengetahui bahwa sesuatu itu buruk namun ia tetap melakukan keburukan tersebut, hal tersebut disebabkan oleh potensi hati tidak digunakan dengan sepenuhnya sehingga manusia lebih mengedepankan nafsu dan melupakan akal.

Ketinggian budi pekerti yang terdapat pada seseorang menjadikannya dapat melaksanakan kewajiban dan pekerjaan dengan baik dan sempurna, yang selanjutnya menjadikan hidup orang tersebutmenjadi bahagia. Sebaliknya apabila manusia tidak memperhatian persoalan akhlak, kasar tabi'atnya, buruk prasangkanya pada orang lain, maka hal itu akan memberikan efek negatif, menjadikanjiwa resah disebabkan karena tidak adanya keserasian dan keharmonisan dalam pergaulan bersosial dan bermasyarakat. ${ }^{1}$

Kehidupan manusia yang makin berkembang dan memasuki babak baru dalam teknologi komunikasi dalam bentuk media sosial dan elektronik tentunya memberikan pengaruh bagi prilaku akhlak anak dan remaja. Referensi tentang akhlak yang dahulu diperoleh dari sekolah, lingkungan dan keluarga hari ini diperkaya dengan informasi yang diperoleh anak melalui televisi dan internet yang memiliki multipatform seperti youtube, facebook, whatsapp, instagram dan sebagainya.

Informasi yang didapat dari media-media tersebut ada yang meberikanefek positif bagi akhlak anak tetapi juga berdampak negatif. kondisi ini tentunya akan menjadi perhatian para pemerhati anak mengenai efek dan dampak dari internet dalam jangka pendek maupun panjang. hal ini dibuktikan dengan pemerintah yang turut mengatur regulasi pada internet melalui Menkominfo dengan memblokir beberapa situs yang dianggap berbahaya bagi 
anak dan remaja. Namun hal ini belum cukup mengingat masih adanya celahcelah yang memungkinkan efek negatif sampai kepada anak.

Pada beberapa keluarga dengan tingkat pendidikan dan kesadaran akan bahaya media internet yang dangkal tidak terlalu mempersoalkan dan memberikan aturan dan batasan yang cukup kepada anak untuk mengakses saluran-saluran tersebut yang kemudian berdampak pada degradasi akhlak pada anak, padahal keluarga dalam Islam merupakan unsur yang sangat penting dalam pendidikan dan pembinaan akhlak.

Untuk mewujudkan pendidikan akhlak anak yang diinginkan oleh Islam haruslah dimulai dari keluarga terlebih dahulu. dalam melaksanakan pendidikan akhlak terhadap anak, keluarga hendaknya memperhatikan betul-betul kondisi keluarga dan anak. Pada keluarga tradisional, satu-satunya kemungkinan bentuk kehidupan keluarga adalah ibu pengurus rumah dan pengasuh anak, sedangkan seorang ayah aktif bekerja di luar rumah saja untuk mencari nafkah. Namun pendidikan akan menjadi berbeda pada keluarga dengan kedua orang tua yang bekerja dan anak yang diasuh oleh pengasuh bayi atau keluarga lainnya. ${ }^{2}$

Pembinaan Akhlak pada anak meskilah dimulai sejak dini karena informasi yang diterima pada masa kanak-kanak akan lebih mempengaruhi perkembangan jiwa dan psikologi anak. Para ahli telah sepakat membagi usia anak kedalam tiga Fase, Fase pertama, dimulai sejak anak lahir sampai usia dua tahun disebut atau disebut juga fase persiapan. Fase Kedua, dari usia dua tahun sampai berusia enam tahun disebut fase permulaan anak-anak, Fase Ketiga, dari usia enam tahun sampai usia dua belas tahun disebut fase paripurna anak. ${ }^{3}$

Merupakan kewajiban orang tua dalam menyiapkan iklim atau suasana lingkungan yang baik bagi anak. Apalagi bilaanak sudah mulai menginjak usia sekolah, peran kedua ini mutlak menjadi penting dalam mengarahkan perkembangan akhlak dan sikap anak. hal ini disebabkan pada masa sekolah merupakan masa yang tepat bagi anak untukmenerima pendidikan dan pengajaran, belajar dan bereksplorasi.Anak sudah berusaha untuk mencapai sesuatu sebagai bentuk perkembangan jiwa melalui berbagai aktivitas. ${ }^{4}$

Jika seorang anak sudah mendapatkan informasi dan hal-hal yang baru dari luar, maka proses tersebut akan berlanjut dengan usaha seorang anak untuk

${ }^{2}$ Dagun, Muhammad.Psikologi Keluarga.(Jakarta: Rineka Cipta. 1995) 5

${ }^{3}$ Mahfudz, Djamaluddin.Psikologi Anak Dan Remaja Muslim.(Jakarta: Pustaka AlKautsar. 2001), 3

${ }^{4}$ Abu Ahmadi and Widodo Supriono, Psikologi Belajar.(Jakarta: Rineka Cipta. 2001), 51 
menunjukan ke"aku"annya. Disinilah orang tua harus mempersiapkan saranasarana yang dapat membantunya melakukan sebuah proses dari satu fase kefase berikutnya. Pada saat ini orang tua dituntut semakin mengerti karakteristik perkembangan kepribadian anak baik dari segi fisik, akal, perasaan dan sosial.

Anak memiliki dua pendidik utama dalam kehidupan mereka, orang tua dan guru. Orang tua merupakan pendidik utama bagi anak hingga ia masuk kedalam usia sekolah, namun tetap saja orang tua menjadi unsur utama yang mempengaruhi anak, apakah anaknya akan belajar melalui sekolah ataupun tidak. Mesikpun demikian orang tua akan tetap menjadi orang yang terdekat bagi anak. ${ }^{5}$ Anak akan selalu meniru apa yang dicontohkan oleh kedua orang tuanya.

Islam memandang anak sebagai amanah dari Allah swt untuk hambanya. Amanah dititipkan kepada orang tua selaku orang yang melahirkan, membesarkan, mengasuh, mendidik dan menyiapkan generasi Islam selanjutnya. Untuk mewujudkan generasi yang Islami, sebelum seorang anak mendapakan pendidikan lain, maka yang terpenting adalah pendidikan akhlak. dan orang tualah yang bertanggung jawab sebagai peletak dasar pendidikan bagi anakanaknya.

Ketika orang tua melibatkan dirinya dalam pendidikan anak mereka, biasanya hasilnya akan lebih positif dan berkualitas. Dalam hal ini, mereka biasanya meniru dan bertindak akhlak orang tuanya yang ditularkan melalui pergaulan dan sikap orang tua dan anak serta akan berpengaruh kepada kemampuan belajar mereka secara keseluruhan. Oleh sebab itu, orang tua harus terlibat dan mendukung pendidikan anak-anak mereka, karena cara ini dan dukungan orang tua merupakan salah satu strategi utama dalam mensukseskan pengajaran anak. Tingkat pengajaran dan pendidikan anak dalam keluarga akan sangat bergantung dengan tingkat pendidikan kedua orang tuanya, jadi faktor ini sangat mempengaruhi hubungan keluarga dan keberhasilan anak. ${ }^{6}$

Jika mendidik anak dengan akhlak yang baik merupakan hal yang telah disepakati, maka orang tua maupun pendidik hendaknya memahami metode, model dan silabus dalam pendidikan Anak. Pengetahuan itu akan membantu untuk mengenali jalan dan cara dan hal-hal apa saja yang mesti ditanamkan pada anak.

${ }^{5}$ Beqja Hamit, Gruaja Kjo Qenie E Shenjte, (Tirane. 2002), 177

${ }^{6}$ Ceka, Ardita dan Murati, Rabije. The Role of Parents in the Education of Children. Journal of Education and Practice, Vol.7, No.5, (2016). 
Terdapat beberapa pandangan mengenai materi dan point-point utama akhlak yang harus diajarkan kepada anak dan harus diperhatikan oleh orang tua dan guru, diantara yang umum digunakan dikalangan pesantren dan madrasah adalah kitab Akblak lil Banin dan Akblak lil Banat tulisan Umar bin Ahmad Baraja. Taisirul Khallaq fi Ilmi Akblaq yang ditulis oleh Hafidz Hasan Mas'udi.

Studi mengenai pemikiran Syeikh Nawawi al-Bantani telah banyak dilakukan seperti yang ditulis oleh MR Hidayatullah mengenai Konsep Tasawuf Syeikh Nawawi al-Bantani, Pendidikan Akhlak Menurut Syeikh Nawawi alBantani dalam kitab Babjatul Wasail bi Syarbil Masail oleh Ahmad hafidz Habiburahman, Nilai-nilai pendidikan Akhlak dalam Kitab maraqil Ubudiyah yang diteliti oleh Asmuri Ismail dan Nilai-Nilai Akhlak pada kitab Nashaihul Ibad oleh Abdul Khamid. Namun pada penelitian ini akan difokuskan pada telaah pandangan mengenai pandangan Syeikh Nawawi al-Bantani mengenai pendidikan akhlak pada anak dan akhlak anak kepada orang tua dan yang menjadi fokus adalah tafsir Marahil Labid dan kitab Maraqil Ubudiyah .

\section{Review Akhlak (Moral) Standar di Barat}

Kata akblak diterjemahkan dalam bahasa inggris dengan kata pollite, ethics dan morals. ${ }^{7}$ Barat sendiri memandang sekolah sebagai institusi yang penting dalam pembentukan moral anak, mereka berupaya membedakan antara antara moral yang telah diterima dan moral yang masih menjadi perdebatan dan kontroversi dalam hal batasan-batasannya, antara pendidikan moral yang harus diarahkan dan moral yang terjadi dan diperoleh anak dengan sendirinya.

Hal yang dilakukan manusia adalah menahan diri untuk dapat sesuai dengan norma prilaku, mengikuti aturan-aturan, hingga kepatuhan terhadap norma tersebut terjadi dibawah alam bawa sadar secara alami. Pembentukan moral sendiri merupakan upaya moral untuk melakukan standar moral tertentu, hingga mereka berharap orang lain mematuhi standar tersebut juga. ${ }^{8}$ Studi mengenai moral telah membagi moral mejadi moral secara emosi dan moral secara kognisi, dan menganggap bakhwa konsep moral dan dan emosi moral adalah berhubungan. Moral emosi seperti rasa welas asih, perasaan bersalah, rasa simpati, merupakan bentuk kepahaman seseorang mengenai konsep moral

\footnotetext{
${ }^{7}$ Baalbaki, Rohi. Maurid (qamus Arabi-Inkliri). (Beirut: Darul Ulum Malayin, 2006), 501.

${ }^{8}$ Hand, Michael. Towards a Theory of Moral Education. Journal of Philosophy of Education, Vol. 48, No. 4 (2014).
} 
kepedulian dan keadilan. Pada pendidikan anak perlu ada sintesa antara emosi moral dan tindakan moral untuk mengembangkan kompetensi moral anak. ${ }^{9}$

\section{Akhlak dalam Islam}

Kata akhlak“خلاق"خلق" merupakan bentuk plural dari kata "خلق" yang secara harfiah bermakna pakaian dan kulit, selain itu dapat bermaknakeadaan jiwa yang tertanam, dan muncul darinya perbuatan jahat ataupun baik tanpa diawali pemikiran atau perintah. ${ }^{10}$ Sedangkan menurut Mahmud Yunus khuluk berarti budi pekerti, perangai, tingkah laku dan akhlak. ${ }^{11}$

Da'iratulMa'arifmenjelaskan bahwa akhlak ialah sifat-sifat manusia yang terdidik. Sedangkan para ahli akhlak merumuskan penjelasan yang berbedabeda, diantaranya menurut al Qurtuby Akhlak adalah Suatu perbuatan manusia yang bersumber dari adab kesopanannya, karena perbuatan itu termasuk bagian dari kejadiannya. Menurut Ibnu Maskawaih Akhlaq adalah keadaan jiwa yang selalu mendorong manusia berbuat, tanpa berfikir lama. Sedangkan menurut alGhazali akhlaq adalah suatu sifat yang tertanam dalam jiwa manusia, yang dapat melahirkan suatu perbuatan yang gampang dilakukan; tanpa diawali dengan pemikiran yang lama. Maka jika sifat tersebut melahirkan suatu tindakan terpuji menurut ketentuan akal dan norma agama, dinamakan akhlaq yang baik. Tetapi manakala ia melahirkan tindakan yang jahat, maka dinamakan akhlaq yang buruk. $^{12}$

\section{Biografi Singkat Syeikh Nawawi al-Bantani}

Syeikh Nawawi Al-Bantani, nama lengkapnya ialah Abu Abdul Mu'thi Muhammad Nawawi bin 'Umar bin Arabi al-Jawi al-Bantani. Ia dilahirkan di kampung Tanara, Kecamatan Tirtayasa Kabupaten Serang, Banten, Jawa Barat, pada tahun $1230 \mathrm{H} / 1813 \mathrm{M}$. Kemudian dia wafat dalam usia 84 tahun, yaitu pada 25 Syawal 1314 H/1897 M. Ditempat kediamannya Shi’ib Ali Mekkah. Jenazahnya dimakamkan dipemakaman Ma'la Mekkah, berdekatan dengan makan Ibnu Hajar dan Siti Asma binti Abu Bakar Ash-Shiddiq. Dia wafat pada saat sedang menyusun sebuah buku yang menguraikan Minhaj ath-Thalibin-nya

\footnotetext{
${ }^{9}$ Malti, Tina. Children's Moral Emotions and Moral Cognition: Towards an Integrative Perspective (San Francisco: Jossey-Bass. 2010), 5 2003), 252

${ }^{10}$ Majma' Lughah Arabiyah, Mu'jam Wasith. (Kairo: Maktabah Syuruq Ad-Dauliyah,

${ }^{11}$ Mahmud Yunus, Kamus Arab-Indonesia.(Jakarta: Rajawali Press, 1992.), 120

${ }^{12}$ Mahyudin, Kuliah Akblak. Tasawnf.Jakarta: Kalam Mulia, 2003), 2-4
} 
Imam Yahya bin Syaraf bin Mura bin Hasan bin Husain bin Muhammad bin Jam'ah Hujam An-Nawawi. ${ }^{13}$

Selain mengajar, mengarang dan menjadi Imam di MasjidAl-Haram, Syeikh Nawawi al-Bantani juga tidak luput memantau perkembangan sosial politik di tanah air melalui muridnya yang berasal dari Indonesia serta menyumbangkan ide-ide dan pemikirannya lewat murid-muridnya.

Syeikh Nawawi adalah tokoh dan ulama yang produktif, Perihal jumlah karya yang di hasilkan oleh Syeikh Nawawi, terdapat perbedaan pendapat. Ada yang mengatakan berjumlah 99 buah dan ada pula yang mengatakan keseluruhan karyanya mencapai 115. diantara karya-karyanya dalam bidang akhlak dan Tasawuf:

1. Bahjat al-Wasa'il bi Syarhil Masa'il, syarah atas kitab Ar-Rasail al-Jami'ah Baina Ushul ad-Din wal-Figh wat-Tasawuf, karya Sayyid Ahmad ibn Zein alHabsyi. Ditulis pada tahun $1292 \mathrm{H}$

2. Fath al-Majid, ulasan dari kitab al-Durr al-Farid Fi al-Tauhid. Di tulis pada tahun $1298 \mathrm{H}$.

3. Tijam al-Darari merupakan ulasan atas kitab al-'alim al-Allamah Syeikh Ibrahim al-Bajuri fi al-Tauhid. Kitab ini ditulis pada tahun $1301 \mathrm{H}$.

4. Al Nabjah al-Jadidah yang ditulis pada tahun $1303 \mathrm{H}$

5. Drari'ah al-yaqin 'ala Umm al-Barahain yang ditulis pada tahun $1317 \mathrm{H}$. kitab ini memberi ulasan pada Umm al-barahain karya al-Sanusi.

6. Salalim al-Fudlala, ringkasan/risalah terhadap kitab Hidayatul Azkiya ila Thariqil Awliya, karya Zeinuddin ibn Ali al-Ma’bari al-Malibari.

7. Nasaih al-Ibad, syarah atas kitab Masa'il Abi Laits, karya Imam Abi Laits.

8. Qami'al Thughyan, syarah atas Syu'ub al Iman, karya Syekh Zaenuddin ibn Ali ibn Muhammad al-Malibari.

9. Marraqi 'Ubudiyyat, syarah atas kitab Bidayatul Hidayah karya Abu hamid ibn Muhammad al-Ghazali.

10.Nur al-Dhalam yang ditulis pada tahun 1329 H. berisi ulasan atas kitab manzumat bi Aqidah al-Awam karya Syeikh Ahmad Marzuki al-Maliki.

${ }^{13}$ Sudirman Tebba, Mengenalkan Wajah Islam Yang Ramah (Jakarta: Pustaka Irfan, 2007), 
Untuk menganalisa dan mendapatkan data mengenai pemikiran Syeikh Nawawi al-Bantanidipilih prosedur penelitian deskriptif yang menyajikan pemikiran, juga dilakukan pengamatan, pencatatan, dan penginterpretasian pemikiran-pemikiran yang ditemukan. Data bersumber dari sumber-sumber pustaka yang berisi pemikiran-pemikiran Syeikh Nawawi. Jenis data dalam penelitian ini bersifat kualitatif. Terhadap pemikiran-pemikiran beliau dilakukan analisa sumatif yang menginterpretasikan apa yang termaktub dalam sumber pustaka.

Penelitian ini juga diperkaya dengan dilakukannya observasi singkat pada Pondok pesantren Syeikh Nawawi di Banten untuk melihat bentuk nyata aplikasi ajaran-ajaran akhlak Syeikh Nawawi dalam bidang pendidikan.

\section{HASIL DAN PEMBAHASAN}

Potret pemikiran Syeikh Nawawi terekam dalam karya-karyanya, yang pada umumnya menampilkan pemikiran tradisionalisme, sufisme dan asketisme. Tradisionalisme dalam banyak pandangan ditandai dengan kecenderungankecenderungan yang sangat kuat pada upaya-upaya mempertahankan kemapanan tradisi. Tradisi lebih lanjut memiliki makna yang sakral dan karena itu perubahan-perubahan atasnya dianggap sebagai 'kesalahan'. Argumen yang acap kali dikemukakan adalah bahwa tradisi yang sudah berjalan dan diamalkan adalah merupakan sesuatu yang pasti. Jika tradisi-tradisi tersebut dianggap sebagai kebaikan, maka harus dipertahankan, karena perubahan adalah spekulasi dan belum jelas baik buruknya.

Meskipun tradisionalisme mewarnai pemikiran Syeikh Nawawi, namun dari sisi lain ia tercatat sebagai pembaharu tradisi pemikiran keagamaan di Indonesia yang Sebelum munculnya gerakan para kiai yang merupakan jebolan Makkah Mukaramah, wacana-wacana keagamaan khususnya fikih adalah wacanawacana sinkretisme kejawen.

Syeikh Nawawi hidup sezaman dengan tokoh pembaharu terkemuka Jamaluddin al-Afgani (1254 -1314 H/1839-1897 M) dan murid utamanya Muhammad Abduh (1266-1323 H/1849-1905 M), tetapi sulit bagi kita untuk dapat menemukan pikiran-pikiran baru dari Syeikh Nawawi yang tersebar sebagaimana pemikiran Al-Afghani dan Muhammad Abduh, hal ini lebih disebabkan oleh konteks sosial dakwah syeikh Nawawi al-Bantani.

Pikiran-pikiran Syeikh Nawawi juga banyak di pengaruhi paradigma sufisme. Dalam tradisi masyarakat Indonesia, Sufisme sering ditampilkan dalam 
aktifitas-aktifitas ritual personal yang intens dalam rangka menyucikan diri dan membersihkan hati guna mendekatkan diri pada Tuhan. Aktifitas-aktifitas ini dipandang lebih utama daripada aktifitas lain yang bersifat sosial.

Melihat karya-karya syeikh Nawawi dapat dipahami beliau menguasai berbagai bidang agama yang tidak diragukan lagi terutama dalam bidang fikih, tauhid dan akhlak. Pada kajian ini wilayah akhlak terkhusus akhlak kepada orang tua yang akan lebih disorot.

AgamaIslam mengajarkan dan mewajibkananak untuk berbakti dan taat kepada ibu dan bapak. Taat dan berbakti kepada kedua orang tua adalah sikap dan perbuatan yang terpuji yang memiliki nilai konvensional agung dalam tradisi masyarakat di Indonesia. Banyak para ahli yang memperhatikan nilai-nilai akhlak ketimuran yang mulai tergerus dengan pengaruh budaya non timur yang memiliki sistem nilai yang berbeda dalam memandang persoalan ini. Keadaan ini memanggil kita untuk kembali melihat bagaiama sesungguhnya sistem akhlak yang telah diajarkan dalam tradisi keagamaan di Indonesia.

Syeikh Nawawi memiliki beberapa pandangan mengenai point-point berbakti dan adab sopan santun yang mesti dipahami dan diaplikasikan dalam kehidupan sebagai anak, hal ini tentu bukan saja perlu diketahui oleh anak namun juga harus diketahui oleh pendidik yang mempunyai tugas menanamkan nilai-nilai akhlak kepada anak sejak dini. Berikut pandangan Syeikh Nawawi alBantani yang disarikan dari berbagai sumber.

Mematubi perintah orang tua selama perintah itu bukan dalam rangka mendurbakai Allah swt. ${ }^{14}$ Mentaati kedua orang tua adalah dengan cara mentaati segala apa yang diperintahkan, bahkan mendahulukan dari perkara-perkara yang sunnah, Seorang anak diwajibkan mendahulukan orang tua dari anak dan istri dan orang lain.Bentuk ketaatanseorang anak kepada orang tuasangat banyak dan luas, mencakup semua dimensi kebajikan selama tidak bertentangan dengan syariat Allah dan Rasullah.

Melayani dan mentaati kedua orang tua merupakan kewajiban selama itu tidak untuk meninggalkan ketaatan kepada Allah, namun apabila mereka mengajak kepada hal-hal yang mendurhakai Allah swt, perintah mereka tidak wajib untuk ditaati, namun berbuat baik kepada keduanya tetap dilakukan karena difardukan secara syari'at dan termasuk menjaga maruah

\footnotetext{
${ }^{14}$ Al-Bantani, Muhammad Nawawi.Terjemah Maroqil 'Ubudiyab:Syarah Bidayah AlHidayah. (Surabaya: Mutiara ilmu, 2000), 289.
} 
seseoang. ${ }^{15}$ Ajakan orang tua untuk syirik kepada Allah swt ataupun mengajak kepada kejahatan yang bertentangan dengan agama, moral dan nilai-nilai kemanusiaan tidak wajib untuk ditaati, demikian juga ajakan yang tidak diketahui kebenarannya, apa yang tidak diketahui kebenarannyatidak boleh mengikutinya.

Perintah untuk berbuat baik kepada kedua orang tua merupakan perintah yang diperintahkan dengan kuat dari Allah swt, dan kebantian kepada orang tua harus dilakukan secara sempurnamengingat apa yang telah dilakukan oleh kedua orang tua merupakan hal yang sangat mulia dan telah mencapai derajat utama, hingga meskipun anak melakukan kebaktian dan berbuat baik, perbuatan itu tidak akan dapat menyamai apa yang telah dilakukan oleh orang tua kepada anak. ${ }^{16}$

Tidak berjalan didepan kedua orang tua, tetapi berjalan disamping atau dibelakangnya. Jika anak berjalan didepan orang tua karena disebabkan sesuatu yang mengharuskan, maka tidaklah mengapa.Merupakan etika yang khusus dalam Islam dimana orang yang lebih muda tidak berjalan didepan orang yang lebih tua meskipun orang itu bukan orang tuan kandung, bahkan meskipun orang tersebut bukan seorang muslim. Hal ini dapat diamati pada kisah terkenal Ali bin Abi Tholib, yang terlambat sholat subuh dikarnakan menghormati orang tua yang beragama Kristen yang berjalan didepannya, Ali bin Abi Thalib menahan diri untuk tidak mendahului orang tua tersebut. ${ }^{17}$

Apabila demikian halnya akhlak kepada orang lain, tentu akhlak kepada orang tua mesti lebih diperhatikan. Dalam pendidikan sekolah, guru merupakan orang tua siswa selama disekolah, maka menanamkan nilai yang terlihat sederhana sesungguhnya memberikan dampak besar bagi anak dikemudian hari.

Tidak mendahului orang yang lebih tua dalam berjalan sesungguhnya melatih empati, kesabaran dan rasa rendah hati pada anakdan membina sikap lemah lembut kepada orang tua, terlebih lagi apabila orang tua tersebut telah memasuki usia manula, maka hal ini menanamkan rasa kasih sayang dan mengikis rasa malu anak atas keadaan kedua orang tuanya yang telah lanjut. ${ }^{18}$

Menjawab panggilan kedua orang tua dengan jawaban yang lemah lembut.Temasuk nilai bakti kepada kedua orang tua yang cukup besar adalah

\footnotetext{
${ }^{15}$ Al-bantani, Muhammad Nawawi. Marabilabid Likasyfi Ma'na Quranil Majid.(Beirut: Darul Kutub Ilmiah. 1996), 237

${ }^{16}$ Ibid.,622

${ }^{17}$ KH. A. Mudjab Mahalli..., 115

${ }^{18}$ Al-bantani, Muhammad Nawawi, Terjemah Maroqil 'Ubudiyah...,289
} 
segera menyahut dan menyambut seruan orang tua, hal ini merupakan bagian dari ibsan, bahkan menjawab panggilan orang tualebih diprioritaskan dari ibadah sunnah.

Menjawab dengan kasar bahkan menjawab kedua orang tua dengan perkataan yang tidak baik bukan hanya menyakiti kedua orang tua namun juga dapat mendatangkan kemurkaan Allah swt, apalagi bila yang disampaikan kedua orang tua berkaitan dengan perintah Allah, larangan berbicara kasar tersebut mencakup perkataan yang kecil maupun yang besar, dan juga dilarang menyelisihi perkataan kedua orang tua bahkan menetang perkataannya tersebut. ${ }^{19}$

Menjawab dengan lemah lembut menjadi kewajiban, meskipun orang tua bersikap ataupun berkata kasar kepada anak maka akhlak anak adalah diam, tidak membantah, bahkan tidak pula menjawab, dan tidak mengangkat suara lebih kuat dari suara mereka. ${ }^{20}$

Mencari keridhaan kedua orang tua dengan perkataan dan perbuatan, rendah hati dan lemah lembut kepada kedua orang tua seperti melayani mereka, menyuapi makan bila keduanya tidak mampu dan mengutamakan keduanya diatas diri dan anak-anaknya, kesemuanya demi mencari keridhaan kedua orang tua.

Pandangan syeikh Nawawi ini bersesuaian dengan hadits Nabi Muhammad yang menyatakan bahwa Ridha Allah swt berada pada ridha kedua orang tua dan kemurkaan Allah swt berada dalam kemurkaan kedua orang tua.

Tidak bermuka cemberut kepada keduanya termasuk salah satu hal yang menurut syeikh Nawawi al-Bantani mesti diajarkan kepada anak, apa yang terjadi hari ini beberapa anak tersenyum ketika bertemu dengan temantemannya tetapi bermuka masam saat bersama orang tuanya. Bermuka gembira dan tersenyum termasuk salah satu kebaikan yang meskipun kecil namun merupakan "ma'ruf" dan bernilai ibadah. Dalam haditsnya Nabi menyatakan; "Janganlah menghina kebaikan yang kecil walaupun bertemu dengan saudaramu dengan berwajah cerah" 21 , dan "senyummu kepada saudaramu adalah

\footnotetext{
${ }^{19} \mathrm{Al}-$ bantani, Muhammad Nawawi, Terjemah Maroqil 'Ubudiyah..., 622

${ }^{20}$ Al-bantani, Muhammad Nawawi, Maraqi Ubudiya.(Beirut: Darul Kutub Islamiyah. 2015), 105.

${ }^{21}$ Muslim An-Naisaburi, Musnad Shabih Muslim Tahqiq Mubammad Fu'ad Abdul Baqi,(Beirut: Darul Ihya' Turats Arabiyah), 473
} 
sedekah" ${ }^{\prime 2}$, apabila kepada orang lain begitu besar nilai senyuman dan bermuka cerah maka bagaimana nilainya bila dilakukan kepada kedua orang tua.

Mengajarkan anak untuk tidak bermuka cemberut merupakan hal yang dapat menanamkan kegembiraan dan sikap dan emosi positif, serta tidak menyakiti hari orang lain yang melihat terutama orang tua, karna apabila anak bermuka masam ataupun cemberut tentu akan menimbulkan tanda tanya dan prasangka orang tua.

Tidak bepergian, kecuali dengan izin keduanya. ${ }^{23}$ Meminta izin merupakan bentuk kepatuhan anak kepada kedua orang tuanya dan memberikan kepahaman kepada anak bahwa dengan meminta izin memberikan kebaikan untuk anak itu sendiri, orang tua menjadi lebih muda untuk mengambil tindakan bila terjadi hal-hal yang tidak diinginkan pada anak.

Haruslah dipahami bahwa meminta izin kepada orang tua bukanlah untuk kepentingan orang tua semata, tetapi lebih dari itu adalah untuk keselamatan anak.

Selain dalam kitab Maraqil 'Ubudiyahdan tafsir Marahil Labid Syeikh Nawawi juga menerangkan dalam Tafsir al-Munir mengenai akhlak anak terhadap orang tua yang terdapat dalam surat al-Isro', ayat 23-25 mengenai perintah kepada manusia untuk menyembah hanya kepada Tuhan saja, dan menyandingkan perintah menyembah kepada Tuhan dengan perintah untuk berbuat baik kepada kedua orang tua, hal ini menunjukkan hal tersebut merupakan hal yang penting.

Bersyukur kepada Allah swt atas anugrah yang diberikan berupa kedua orang tua yang beriman dan mendo'akan keduanya, dalam marabil labid diceritakan mengenai Abu Bakar yang bersukur kepada Allah SWT atas kenikmatan yang diberikan berupa kedua orang tua dan anak-anak yang beriman kepada Allah SWT, sehingga ia berdoa dan bersyukur. Hal ini merupakan suatu bentuk akhlak kepada Allah SWT dan akhlak kepada kedua orang tua, mendoakan dan bersyukur.

Ajaran-ajaran syeikh Nawawi al-Bantani sangat perlu untuk kembali ditanamkan kepada anak, ajaran-ajaran beliau sangat menekankan kepada

22Tirmidzi, Al-Jami' al Kabir Sunan Tirmidzi. (Beirut: Darul Gharb Islami. 1998), 479.

${ }^{23}$ Muhammad Nawawi Al-Bantani, Terjemah Maroqil 'Ubudiyab: Syarah Bidayah AlHidayah. (Surabaya: Mutiara ilmu, 2000), 289-290. 
tindakan akhlak dan kognisi akhlak dalam membentuk kompetensi akhlak yang kamil pada anak, dan moral yang dibangun dimulai dari orang yang terdekat dengan anak sehingga akan dapat memberikan pembiasaan-pembiasaan yang terbentuk di alam bawah sadar seorang anak.

Mendidik anak dengan akhlak yang baik sejak dini juga akan menjadikan anak lebih mematuhi norma-norma, hingga akan menjadikannya bersikap dan berakhlak dengan akhlak yang baik.

\section{KESIMPULAN}

Akhlak merupakan hal mendasar yang harus menjadi perhatian dalam pendidikan pada sekolah-sekolah, mengingat akhlak tidak bisa dibentuk dalam waktu yang relatif singkat. Melihat perkembangan teknologi informasi serta persentuhan kebudayaan yang begitu cepat, tergerusnya akhlak nusantara yang dibangun diatas nilai-nilai religi dan adat serta kearifan lokal menjadi persoalan yang terus berlanjut.Pandangan Syeikh Nawawi yang merupakan salah satu ulama klasik Indonesia bahkan Nusantara masih sangat relevan untuk dijadikan rujukan dalam menyusun pendidikan anak kepada orang tua. Ajaran-ajaran tersebut mengarah kepada pembentukan kompetensi akhlak yang bukan berhenti pada akhlak dalam tatasan kognisi saja, melainkan lebih kepada tindakan akhlak dalam membentuk calon-calon generasi yang cerdas secara intelektual dan emosional dan memadukan antara ketaatan kepada Tuhan dan kebaktian kepada kedua orang tua.

\section{DAFTAR PUSTAKA}

Abu Ahmadi dan Widodo Supriono, 2001. Psikologi Belajar. Jakarta: Rineka Cipta.

Al-Bantani, Muhammad Nawawi, 2015.Maraqi Ubudiyah. Beirut: Darul Kutub Islamiyah.

Al-Bantani, 1996. Muhammad Nawawi. Marabilabid Likasyfi Ma'na Quranil Majid. Beirut: Darul Kutub Ilmiah.

Al-Bantani, Muhammad Nawawi, 2000.Terjemah Maroqil 'Ubudiyah: Syarah Bidayah Al-Hidayah. Surabaya: Mutiara Ilmu.

Asmaran As, 1992. Pengantar Studi Akblak. Jakarta: Raja Grafindo Persada.

Beqja Hamit, 2002.Gruaja kjo qenie e shenjte, Tirane.

Baalbaki, Rohi, 2006. Maurid (Kamus Arabi-Inkliri). Beirut: Darul Ulum Malayin. 
126 | AR-RIAYAH : Jurnal Pendidikan Dasar vol. 2, no. 2, 2018

Ceka, Ardita dan Murati, Rabije. The Role of Parents in the Education of Children. Journal of Education and Practice, Vol.7, No.5, (2016).

Dagun, 1995. Muhammad. Psikologi Keluarga . Jakarta: Rineka Cipta.

Hand, Michael. Towards a Theory of Moral Education. Journal of Philosophy of Education, Vol. 48, No. 4 (2014).

Malti, Tina, 2010.Children's Moral Emotions and Moral Cognition: Towards an Integrative Perspective. San Francisco: Jossey-Bass.

Majma’ Lughah Arabiyah, 2003.Mu'jam Wasith. Kairo: Maktabah Syuruq AdDauliyah.

Mahmud Yunus, 1992. Kamus Arab-Indonesia. Jakarta: Rajawali Press.

Mahyudin, 2003.Kuliah Akhlak Tasawuf. Jakarta: Kalam Mulia.

Sudirman Tebba, 2007. Mengenalkan Wajah Islam Yang Ramah. Jakarta: Pustaka Irfan.

Muslim An-Naisaburi, Musnad Shahib Muslim Tahqiq Muhammad Fu'ad Abdul Baqi, Beirut: Darul Ihya' Turats Arabiyah.

'Tirmidzi,1998. Al-Jami' al Kabir Sunan Tirmidzi. Beirut: Darul Gharb Islami.

Muhammad Nawawi Al-Bantani, 2000. Terjemah Maroqil 'Ubudiyah: Syarah Bidayah Al-Hidayah. Surabaya: Mutiara ilmu. 